\title{
PENGEMBANGAN MULTIMEDIA PEMBELAJARAN BAHASA ARAB UNTUK MAHASISWA UIN SUNAN KALIJAGA YOGYAKARTA
}

\author{
Lili Suryani, Ishartiwi \\ Program Studi Teknologi Pembelajaran PPs UNY, Universitas Negeri Yogyakarta \\ lee_adin24@yaho.com, buisyk@yahoo.com
}

\begin{abstract}
Abstrak
Penelitian ini bertujuan untuk: menghasilkan dan mengetahui kefektifan penggunaan multimedia pembelajaran bahasa Arab untuk mahasiswa UIN Sunan Kalijaga Yogyakarta. Penelitian ini menggunakan model penelitian dan pengembangan (R\&D) dengan subjek penelitian mahasiswa semester I prodi Pendidikan Bahasa Arab Fakultas Tarbiyah dan Keguruan UIN Sunan Kalijaga Yogyakarta. Untuk uji validitas multimedia dilakukan oleh 2 orang ahli materi dan 2 orang ahli media. Instrumen pengumpulan data berupa angket untuk mengetahui kelayakan produk yang dikembangkan dan untuk mengetahui keefektifan penggunaan multimedia dilaksanakan pembelajaran menggunakan multimedia hasil pengembangan dan tes hasil belajar. Penelitian pengembangan ini menghasilkan multimedia pembelajaran bahasa Arab berbentuk CD pembelajaran dilengkapi manual book dengan materi "حياتتا اليومية" (kehidupan sehari-hari). Kelayakan produk berdasarkan validasi ahli materi dengan hasil "sangat baik" (4,45 dan 4,5), validasi ahli media dengan hasil "sangat baik" $(4,34$ dan 4,95) dan multimedia yang efektif berdasarkan hasil uji keefektifan penggunaan multimedia hasil pengembangan diperoleh rerata sebesar 64,5 saat pre-test dan diperoleh rata-rata 87,9 saat post-test sehingga diperoleh gain score 23,4 poin. Berdasarkan hasil evaluasi tersebut maka multimedia pembelajaran bahasa Arab hasil pengembangan dalam penelitian ini layak dan efektif digunakan untuk pembelajaran.
\end{abstract}

Kata kunci: multimedia, bahasa Arab

\section{THE DEVELOPMENT OF INSTRUCTIONAL MULTIMEDIA ARABIC LANGUAGE FOR STUDENT ISLAMIC STATE UNIVERSITY (UIN) SUNAN KALIJAGA YOGYAKARTA}

\author{
Lili Suryani, Ishartiwi \\ Program Studi Teknologi Pembelajaran PPs UNY, Universitas Negeri Yogyakarta \\ lee_adin24@yaho.com, buisyk@yahoo.com
}

\begin{abstract}
This study aimed to produce and determine the effectiveness of the use of a multimedia language learning multimedia Arabic for the student of Arabic Language Education Program Faculty of Tarbiyah and Teaching UIN Sunan Kalijaga Yogyakarta. This study uses a model of research and development (RED) with the subjects in this study were students of the first semester study program faculty Tarbiyah and Teaching UIN Sunan Kalijaga Yogyakarta. To test the validity of multimedia made by 2 people matter experts and and 2 people media experts. Data collection instruments such as questionnaires to determine the feasibility of products developed and to determine the effectiveness of the use of learning undertaken using multimedia development results and achievement test. This results in the development of research is multimedia learning Arabic decent education study program learning CD comes with a manual book material "حياتنا اليومية". Feasibility products based validation matter experts with the results "very good" (4.45 and 4.5), validation of media experts with the results "very good" (4.34 and 4.95) and than effective multimedia based on the results of testing the effectiveness of the use of multimedia results obtained the average development time of 64.5 while the pre-test student learning outcomes at post-test obtained an average score of 87.9 to obtain a gain of 23.4 points. Based on the results of the evaluation of multimedia learning Arabic in the development of the research results is feasible and effective using for studing.
\end{abstract}

Keywords: multimedia, Arabic 


\section{Pendahuluan}

Program Pendidikan Bahasa Arab UIN Sunan Kalijaga merupakan Program pendidikan yang dirancang untuk menyiapkan calon tenaga pendidikan Islam yang profesional, khususnya sebagai tenaga ahli/guru bahasa Arab di sekolah umum dan madrasah. (UINSUKA, 2006, p.20). Lulusan Prodi Pendidikan Bahasa Arab diharapkan tidak hanya mampu berbahasa Arab baik lisan maupun tulisan tetapi juga mampu mengajarkannya secara profesional.

Berdasarkan hasil wawancara yang diajukan pada beberapa mahasiswa Prodi Pendidikan Bahasa Arab angkatan 2009 dan 2010 pada tanggal 23 Juli 2011, diketahui bahwa dengan latar belakang pendidikan berbasis Bahasa Arab seperti madrasah dan pesantren menjadikan sebagian mahasiswa telah memahami bahasa Arab secara global, sehingga mahasiswa membutuhkan inovasi dalam pembelajaran bahasa Arab, seperti media atau multimedia pembelajaran.

Selanjutnya, peneliti melakukan observasi keadaan pembelajaran dan fasilitas yang ada di ruang kelas Prodi Pendidikan Bahasa Arab pada tahun 2011, diketahui bahwa ada beberapa fasilitas media pembelajaran berbasis information technology (IT) yang belum dimanfaatkan, seperti CD proyektor yang ada di ruang kelas dan beberapa laptop yang dimiliki mahasiswa, karena mahasiswa hanya menggunakan buku referensi bahasa Arab.

Kurangnya pemanfaatan LCD proyektor yang ada di ruang kelas dan laptop yang dimiliki mahasiswa secara pribadi ini disebabkan oleh belum ada multimedia pembelajaran yang sesuai dengan buku bahasa Arab yang digunakan oleh mahasiswa dan dosen.

Fenomena yang telah peneliti uraikan diatas menunjukkan belum adanya media pendukung untuk memanfaatkan LCD proyektor dan laptop yang telah tersedia. Kim \& Gillman (2008) dalam Journal Educational Technology \& Society dengan penelitian yang berjudul "Effect of text, audio, and graphic aids in multimedia instruction for vocabulary learning". Memberikan kesimpulan bahwa penggunaan multimedia pembelajaran yang menampilkan gambar ilusi merupakan salah satu cara efektif untuk meningkatkan hasil belajar.

Adapun fokus dalam penelitian ini pada permasalahan belum adanya multimedia pembelajaran bahasa Arab yang sesuai dengan tema حياتنا اليومية (kehidupan sehari-hari) yang dibahas dalam mata kuliah bahasa Arab di Prodi Pendidikan Bahasa Arab UIN Sunan Kalijaga Yogyakarta. Sehingga penelitian ini bertujuan untuk mengembangkan dan menghasilkan serta mengetahui efektivitas multimedia pembelajar-an bahasa Arab dengan tema (kehidupan sehari-hari) dalam proses pembelajaran agar dapat memanfaatkan media berbasis IT yang telah tersedia di ruang kelas.

CD pembelajaran ini merupakan solusi dari problem dan kesenjangan yang dihadapi oleh mahasiswa Prodi Pendidikan Bahasa Arab Fakultas Tarbiyah dan Keguruan UIN Sunan Kalijaga agar dapat memanfaatkan fasilitas media berbasis IT yang ada di ruang kelas secara maksimal dalam proses pembelajaran bahasa Arab. CD pembelajaran bahasa Arab yang dikembangkan ini juga bermanfaat bagi mahasiswa dalam mengembangkan maharatu al-lughah al-a'rabiyah (kompetensi bahasa Arab) karena dikemas dalam CD agar dapat mempermudah mahasiswa dalam belajar baik secara kelompok maupun individu

\section{Metode Penelitian}

Model Pengembangan

Penelitian ini menggunakan model penelitian dan pengembangan (R\&D) dengan melakukan empat tahapan prosedur pengembangan yaitu (1) analisis kebutuhan; (2) desain pembelajaran; (3) produksi/ pengembangan media; (4) evaluasi. 
Prosedur Pengembangan

\section{Analisis Kebutuhan}

Studi pustaka, mengumpulkan informasi yang berkaitan dengan pengembangan multimedia pembelajaran bahasa Arab, standar kompetensi, kompetensi dasar dan indikator pembelajaran bahasa Arab, buku yang digunakan serta informasi berkaitan dengan pentingnya multimedia pembelajaran bahasa Arab berdasarkan wawancara dengan dosen pengampu mata kuliah bahasa Arab dan mahasiswa.

Studi lapangan, mengumpulkan data dari kampus UIN Sunan Kalijaga Yogyakarta dengan kebutuhan mahasiswa dan dosen dalam pembelajaran bahasa Arab, mengidentifikasi potensi yang dimiliki Fakultas Tarbiyah dan Keguruan serta Prodi Pendidikan Bahasa Arab UIN Sunan Kalijaga Yogyakarta yang dapat dimanfaatkan untuk mengembangkan multimedia pembelajaran. Potensi tersebut antara lain seperti laboratorium komputer, kondisi pembelajaran bahasa Arab, jumlah mahasiswa dan karakteristik mahasiswa. Studi lapangan ini dilakukan dengan cara peninjauan ke Fakultas dan Prodi Pendidikan Bahasa Arab, wawancara kepada mahasiswa dan dosen pengampu mata kuliah bahasa Arab

\section{Desain Pembelajaran}

Desain pembelajaran yang digunakan dalam penelitian ini merujuk pada model Dick and Carrey (2005, pp.1-2) yang mengembangkan model desain pembelajaran dalam bentuk system aproach model for designing instruction yang dapat dijabarkan sebagai berikut:

- Mengidentifikasi standar kompetensi mata kuliah Bahasa Arab dengan menyesuaikan pada kesulitan dan kemudahan materi yang terdapat pada buku “العربية للحياة 1, 2, dan 3.

- Menganalisis dan menetapkan kompetensi dasar dengan menyesuaikan pada standar kompetensi yang telah ditentukan. Kemudian mengidentifikasi karakteristik awal mahasiswa dengan bertanya langsung pada mahasiswa dan dosen pengampu tentang minat dan tingkat kemampuan berbahasa Arab.

- Merumuskan indikator keberhasilan pembelajaran mata kuliah Bahasa Arab

- Mengembangkan latihan dan evaluasi

- Mengembangkan dan memilih materi pembelajaran

- Menyusun strategi pembelajaran menggunakan multimedia pembelajaran

- Membuat flowchart yaitu membuat diagram alur yang akan digunakan sebagai alur navigasi dari multimedia pembelajaran bahasa Arab yang dikembangkan

- Membuat storyboard yang bertujuan untuk membuat frame-frame yang tepat, dan menarik serta rencana yang baik menempatkan navigasi, clipart image, animasi, foto, audio yang sesuai dengan tema materi.

\section{Produksi/ Pengembangan Multimedia}

Dalam penelitian ini tahap produksi/pengembangan media ini dilakukan melalui langkah-langkah yang dikemukakan oleh Philips (1997, p.38) sebagai berikut.

- Mengumpulkan bahan multimedia seperti materi, clipart image, animasi, foto, audio, dan lain-lain yang sesuai dengan materi dan digunakan untuk membuat multimedia pembelajaran bahasa Arab.

- Memasukkan dan menggabungkan bagian-bagian multimedia dengan menggunakan program utama Adobe Flash CS3 berdasarkan storyboard dan flowchart view, merekam suara dengan menggunakan program Cool Edit Pro 2.0.

- Mengemas produk awal ke dalam CD/ Flashdisk

- Tes secara modular yaitu tes yang dilakukan untuk memastikan apakah hasil awal pemuatan multimedia sesuai dengan flowchart maupun storyboard yang direncanakan seperti kecocokan warna dan gambar, materi, dan lainnya.

\section{Evaluasi}

- Memvalidasi produk pada dua orang ahli materi yaitu dosen pengampu mata kuliah Bahasa Arab Prodi PBA UIN Sunan Kalijaga yang difokuskan untuk 
memvalidasi aspek pembelajaran yaitu tujuan pembelajaran, standar kompetensi dan kompetensi dasar, kesesuaian materi dengan peserta didik serta tingkat kesulitan dan kemudahan dalam urutan penyajian materi. Validasi media juga dilakukan oleh 2 orang ahli media dan validasi ini difokuskan pada aspek multimedia yaitu animasi, gambar, audio, kesesuaian elemen-elemen media yang disatukan dan lainnya yang kemudian dilanjutkan dengan analisis data, dan revisi produk berdasarkan review ahli materi, dan ahli media.

- Melakukan uji coba satu-satu (one to one trial), yaitu pada 3 orang mahasiswa prodi PBA UIN Sunan Kalijaga, dilanjutkan dengan analisis data, dan revisi produk berdasarkan hasil uji coba tersebut.

- Melakukan uji coba kelompok kecil (small group evaluation), yaitu pada 10 orang mahasiswa, dilanjutkan dengan analisis data, dan revisi produk berdasarkan hasil uji coba kelompok kecil.

- Melakukan uji coba lapangan (field trial), yaitu pada 20 orang mahasiswa, dilanjutkan dengan analisis data, dan revisi produk berdasarkan hasil uji coba tersebut, sehingga menghasilkan produk final.

- Menggunakan multimedia hasil pengembangan dalam pembelajaran bahasa Arab untuk mengetahui keefektifan dan kelayakan multimedia berdasarkan kualitas hasil belajar bahasa Arab mahasiswa setelah menggunakan multimedia pembelajaran bahasa Arab. Pembelajaran dilakukan oleh peneliti dan dosen pengampu mata kuliah bahasa Arab dengan melibatkan 29 orang mahasiswa. Proses ini dilaksanakan dengan diawali pre-test, dilanjutkan dengan proses pembelajaran dengan menggunakan produk hasil pengembangan kemudian diakhiri dengan pelaksanaan post-test.

Uji coba kelompok kecil dan uji coba lapangan dilakukan untuk mengetahui ketertarikan mahasiswa dalam menggunakan $\mathrm{CD}$ pembelajaran bahasa Arab serta untuk mengetahui kelayakan penggunaan multimedia yang dikembangkan. Dalam pelaksanaan uji coba mahasiswa belajar menggunakan multimedia pembelajaran bahasa Arab secara klasikal dengan menggunakan komputer dan proyektor yang telah tersedia di laboratorium komputer. Kemudian mahasiswa akan belajar secara kelompok dan atau individu dengan menggunakan $\mathrm{CD}$ pembelajaran bahasa Arab yang dikembangkan. Mahasiswa juga dibagikan angket untuk diisi dan menjawab secara jujur ketertarikan dan kemudahan mengakses multimedia yang dikembangkan. Mahasiswa diberikan space di dalam angket untuk menuliskan saran dan kritik terhadap multimedia yang dikembangkan.

\section{Waktu dan Tempat Penelitian}

Pada bulan September-Oktober 2012 di Laboratorium Fakultas Tabiyah dan Keguruan UIN Sunan Kalijaga Yogyakarta

\section{Desain Uji Coba Produk}

- Tahap pendahuluan menjelaskan dan mengenalkan secara langsung produk yang dikembangkan kepada mahasiswa dan mempraktikkan cara penggunaan multimedia dan belajar bersama mahasiswa secara klasikal dengan menggunakan CD pembelajaran yang dikembangkan.

- Tahap pelaksanaan meliputi proses pembelajaran dan observasi kondisi pembelajaran dengan cara CD pembelajaran bahasa Arab dibagikan atau digandakan dengan menggunakan flashdisk di komputer atau laptop mahasiswa untuk dipelajari secara individu.

- Membagikan angket kepada mahasiswa untuk mengetahui penilaian mahasiswa terhadap kualitas produk dari tingkat kemudahan, kejelasan, dan daya tarik CD pembelajaran yang dikembangkan.

- Tahap akhir meliputi proses analisis hasil angket dari mahasiswa untuk merevisi produk multimedia yang sedang dikembangkan. 
- Setelah uji coba produk dilaksanakan, peneliti menggunakan produk untuk proses pembelajaran di kelas, proses pembelajaran diawali dengan pre-test, dilanjutkan dengan pembelajaran dan diakhiri dengan post-test.

- Tahap analisis hasil pre-test dan post-test digunakan untuk mengetahui kualitas hasil belajar bahasa Arab mahasiswa setelah menggunakan produk.

\section{Subjek Ujicoba}

Subjek ujicoba dalam penelitian pengembangan ini adalah mahasiswa Prodi Pendidikan Bahasa Arab UIN Sunan Kalijaga semester I. Pengambilan data dibagi sebanyak tiga kali dengan mahasiswa yang berbeda. Sampel uji coba satu-satu terdiri atas 3 orang mahasiswa, uji kelompok kecil 10 orang mahasiswa dan uji lapangan 20 orang mahasiswa dan responden untuk kegiatan pembelajaran berjumlah 29 orang mahasiswa.

\section{Jenis Data}

Jenis data yang diperoleh pada penelitian ini adalah data kuantitatif dan data kualitatif yang kemudian dianalisis secara statistik deskriptif. Data kuantitatif diperoleh dari angket berupa skor penilaian dari mahasiswa, ahli materi dan ahli media dengan menggunakan skala 5 dengan rentang nilai: 5 untuk kategori sangat baik, 4 untuk kategori baik, 3 untuk kategori sedang, 2 untuk kategori kurang dan 1 untuk kategori sangat kurang. Dan skor hasil pre-test dan post-test, dilakukan dengan pemberian bobot 1 untuk tiap jawaban yang benar dan mencari persentase untuk memberikan nilai akhir.

Untuk data kualitatif diperoleh dari komentar dan saran dari mahasiswa, ahli materi dan ahli media. Kemudian dideskripsikan sebagai bahan pertimbangan untuk merevisi dan menyempurnakan multimedia pembelajaran bahasa Arab yang dikembangkan. Data kualitatif maupun kuantitatif yang diperoleh tersebut dimaksudkan untuk melihat kualitas dari masing-masing komponen pengembangan multimedia pembelajaran, agar dapat digunakan dalam proses pembelajaran.

\section{Instrumen Pengumpulan Data}

Instrumen pengumpulan data yang digunakan berupa lembar angket. Angket digunakan untuk mengetahui kelayakan produk yang dikembangkan dari aspek pembelajaran, isi, tampilan, dan pemrograman serta untuk mengukur aspek kemudahan, manfaat, kejelasan dan daya tarik multimedia bagi user. Serta soal pretest dan post-test yang terdiri atas 10 soal pilihan ganda tentang tes evaluasi materi حياتتا اليومية

Data yang dihimpun dari angket kemudian dianalisis dengan menggunakan teknik analisis deskriptif

\section{Validitas dan Reliabilitas Instrumen}

Validitas instrumen dalam penelitian ini terdiri atas validasi teoretis dan validasi empiris (Sukardjo, 2006, p.57). Validasi teoretis berupa pembuatan kisikisi angket untuk ahli materi, ahli media dan mahasiswa, serta pembuatan kisi-kisi soal pre-test dan post-test. Validasi empiris berupa validasi instrument butir soal tes evaluasi materi yang berjumlah 20 soal. Validasi empiris dilakukan dalam pertemuan kelas oleh peneliti dan dibantu oleh dosen pengampu mata kuliah bahasa Arab. Proses validasi ini melibatkan 27 mahasiswa. Analisis uji coba butir soal dilakukan dengan menggunakan program iteman. Butir soal yang sudah dihitung dengan program iteman ditentukan tingkat validitasnya dengan pedoman Kriteria tingkat kesukaran (proportion Correct (Sukardjo, 2006, pp.58-61)

Berdasarkan analisis, terdapat 17 butir soal yang valid dari 20 butir soal yang diujicobakan. Butir soal yang valid dianalisis kembali dengan program iteman untuk mencari tingkat reliabilitas. Hasil analisis menunjukkan bahwa soal reliabel dengan nilai $0,822 \geq 0,306$ sesuai dengan pendapat Ferguson \& Takane, reliabilitas soal dikatakan baik jika $r_{\text {hitung }} \geq 0.306$ (Hamzah Uno, Herminanto Sofyan \& I 
Made Candiasa, 2001:161). Dari 17 butir soal yang valid dan reliabel, dipilih 10 butir soal untuk pelaksanaan pre-test dan posttest karena seluruh butir soal sudah mewakili tiap indikator dari kompetensi yang diharapkan dan jumlah soal sesuai dengan alokasi waktu dalam proses pembelajaran.

Teknik Analisis Data

Data yang diperoleh melalui observasi dan angket berupa kritik dan saran pada saat uji coba, data dianalisis dan dideskripsikan secara deskriptif kualitatif untuk merevisi produk yang dikembangkan. Sedangkan data kuantitatif yang diperoleh melalui angket penilaian akan dianalisis dengan statistik deskriptif kemudian di konversikan ke data kualitatif dengan skala 5 untuk mengetahui kualitas produk. Konversi yang dilakukan terhadap data kualitatif mengacu pada rumus konversi yang dikemukakan oleh Sukardjo (2005, p.55)

Sedangkan untuk skor hasil pre-test dan post-test dianalisis dengan membandingkan skor. Peningkatan yang terjadi sebelum kegiatan pembelajaran dengan menggunakan multimedia dan sesudah pembelajaran diperhitungkan dengan rumus gain skor (N-gain) yang ditentukan berdasarkan rata-rata gain skor yang dinormalisasi (g) yaitu perbandingan dari skor gain.

\section{Hasil Penelitian dan Pembahasan}

Data Proses Pengembangan

\section{Hasil Studi Pendahuluan}

Multimedia Pembelajaran Bahasa Arab dikembangkan berdasarkan fakta dan data yang diperoleh dari analisis kepustakaan, observasi, wawancara dan uji coba penggunaan multimedia dalam pembelajaran bahasa Arab. Penelitian diawali dengan melakukan studi pendahuluan di Prodi Pendidikan Bahasa Arab Fakultas Tarbiyah dan Keguruan UIN Sunan Kalijaga pada bulan September 2012. Pada studi pendahuluan kegiatan yang dilakukan adalah studi pustaka dan studi lapang- an. Data yang diperoleh dari studi tersebut adalah:

\section{Studi Pustaka (need analysis)}

Berdasarkan data yang diperoleh selama need analysis melalui studi pustaka diketahui bahwa: (1) buku yang digunakan dalam pembelajaran bahasa Arab adalah العربية للحياة jilid 1, 2 dan 3, (2) standar kompetensi pembelajaran bahasa Arab adalah agar mahasiswa mampu memahami, mengekspresikan (mengungkapkan kembali) dan munazharah (saling mengungkapkan argumen) materi yang telah disampaikan melalui al-istima', al-kalam, alqira'ah dan al-kitabah dan atau tarjamah dengan baik, (3) Dosen pengampu dan mahasiswa berpendapat bahwa penggunaan multimedia dalam pembelajaran bahasa Arab sangat penting untuk mendukung tercapainya kompetensi yang diinginkan, (4) materi mata kuliah bahasa Arab sangat menarik tetapi penyampaian materi kurang bervariasi, sehingga terasa sulit untuk dipahami.

\section{$\underline{\text { Studi Lapangan }}$}

Berdasarkan hasil wawancara yang dilakukan dengan dosen pengampu mata kuliah bahasa Arab R. Umi Baroroh.M.Ag dapat diketahui bahwa hasil belajar mahasiswa masih bervariasi mulai dari yang paling tinggi hingga yang paling rendah sehingga perlu peningkatan kualitas hasil belajar. Data yang diperoleh berdasarkan observasi dan wawancara terhadap 5 orang mahasiswa yaitu: (1) Fakultas Tarbiyah dan Keguruan UIN Sunan Kalijaga memiliki laboratorium komputer yang layak untuk digunakan dalam pembelajaran bahasa Arab dengan menggunakan multimedia karena laboratorium komputer dilengkapi dengan 15 unit komputer, 1 buah proyektor yang tersambung dengan komputer operator dan dilengkapi dengan speaker aktif dan headsed, (2) multimedia yang digunakan dalam pembelajaran bahasa Arab masih sangat kurang dan hanya menggunakan buku العربية للحياة, (3) dosen pengampu dan mahasiswa mampu meng- 
operasikan komputer dan laptop yang dibuktikan dengan adanya program pelatihan komputer untuk mahasiswa, serta dosen dan beberapa mahasiswa telah memiliki laptop.

\section{Desain Pembelajaran}

Setelah melakukan analisis kebutuhan, diperoleh informasi berdasarkan hasil wawancara kepada mahasiswa dan dosen pengampu mata kuliah bahasa Arab dapat disimpulkan bahwa:

- Standar Kompetensi (SK) yang harus dicapai adalah mahasiswa mampu memahami, mengekspresikan dan munazharah (berargumen) tentang materi yang disampaikan. Dengan Kompetensi Dasar (KD) mahasiswa mampu memahami materi حياتنا اليومية melalui mendengar dan membaca serta mampu memproduksi dengan berbicara dan menulis.

- Karakteristik mahasiswa PBA UIN Sunan Kalijaga Yogyakarta berdasarkan hasil wawancara diketahui bahwa mahasiswa mampu mengoperasikan komputer atau laptop dan telah mendapatkan pelatihan secara intensif di laboratorium komputer fakultas, sangat tertarik dengan inovasi teknologi sehingga diberikan materi tentang program dan software untuk mengoperasikan komputer, dan memiliki tingkat kemahiran berbahasa Arab yang berbedabeda sesuai dengan hasil ujian tengah semester, memiliki latar belakang pendidikan berbasis bahasa Arab seperti pesantren dan madrasah.

- Indikator keberhasilan yang ditentukan ialah mahasiswa mampu mengungkapkan kembali materi syafahiyyan (secara lisan), membaca dengan benar baik dari aspek kaidah lughawiyah (bahasa) maupun aspek al-nabr wa al-tan-ghim (stile), menjawab pertanyaan kandungan materi yang telah disampaikan dengan benar, menyimpulkan kandungan materi dengan bahasa Arab sesuai kaidah qawa id, menterjemahkan kalimat-kalimat dalam teks dengan terjemah Indo- nesia yang komunikatif, mengungkapkan kandungan teks dengan bahasa Arab, menganalisa teks dalam perspektif kaidah bahasa Arab.

- Instrumen penilaian yang digunakan berupa 10 soal pilihan ganda yang mencakup 4 kompetensi berbahasa sesuai dengan rumusan standar kompetensi dan kompetensi dasar yang dicapai dalam pembelajaran bahasa Arab.

- Materi pembelajaran yang dipilih dan dikembangkan mengacu pada satuan acara perkuliahan (SAP) mata kuliah Bahasa Arab PBA UIN Sunan Kalijaga Yogyakarta dan buku العربية للحياة jilid 1, 2 dan 3.

- Pembelajaran dilaksanakan di laboratorium komputer Fakultas Tarbiyah dan Keguruan UIN Sunan Kalijaga Yogyakarta dengan cara masing-masing mahasiswa mengoperasikan 1 unit komputer yang telah dilengkapi dengan fasilitas CD ROOM atau USB untuk menggandakan file multimedia dan speaker untuk menampilkan multimedia pembelajaran. Mahasiswa diberikan penjelasan tentang penggunaan multimedia dan belajar secara mandiri.

\section{Produksi/Pengembangan Multimedia}

Pada tahap pengembangan multimedia ini kegiatan yang dilakukan adalah:

- Membuat flowcharts view multimedia pembelajaran bahasa Arab sebagai bagan alur pengembangan multimedia pembelajaran bahasa Arab.

- Mengumpulkan bagian-bagian multimedia berupa materi yang disusun dari 3 buku Bahasa Arab untuk mahasiswa, gambar siluet yang diedit melalui corel draw X5 berupa gambar siluet tubuh manusia, pesawat terbang, kompas, kalender, kertas dan angka-angka yang diacak, logo kampus UNY bersumber dari internet (www.google.com/logo kampus/uny), dan audio berupa rekaman suara percakapan dan suara mufrodat berbentuk mp3 yang direkam melalui program Cool Edit Pro 2.0. Musik latar belakang yang digunakan adalah 
musik instrumental tanpa lirik dari lagu Maher Zein berjudul for the rest of my life yang diunduh dari website youtube.

- Membuat storyboards multimedia pembelajaran bahasa Arab untuk menggambarkan bentuk tampilan setiap frame dalam multimedia yang dikembangkan.

- Menggabungkan bagian-bagian multimedia yang telah dikumpulkan dan dikembangkan dengan menggunakan program Adobe Flash CS3 berdasarkan storyboard dan flowchart view. Adapun software-software yang digunakan sebagai pendukung dalam pengembangan multimedia pembelajaran bahasa Arab ini adalah: Adobe Flash CS3 sebagai software utama dalam pengembangan multimedia, Corel Draw X5 sebagai software yang berfungsi dalam pembuatan dan pengeditan gambar siluet yang digunakan dalam multimedia, Cool Edit Pro 2.0 sebagai program untuk merekam suara baik dalam bentuk percakapan maupun mufrodat.

- Tes secara modular dilakukan untuk memastikan hasil awal pemuatan multimedia sesuai dengan flowchart maupun storyboard yang direncanakan seperti kecocokan warna dan gambar, materi, audio dan lainnya. Tes secara modular ini juga dilakukan untuk mengetahui jalannya program secara keseluruhan dan pengetesan ke beberapa komputer yang menggunakan Windows yang berbeda namun memiliki spesifikasi yang setara.

Multimedia pembelajaran bahasa Arab telah selesai dikembangkan, secara keseluruhan berisi:

- الإرشاد yaitu berisi petunjuk penggunaan multimedia pembelajaran bahasa Arab.

- المقدّمة yaitu berisi rumusan standar kompetensi, kompetensi dasar dan indikator

- المادّة berisi materi yang terdiri atas 5 judul materi dan disetiap materi telah dilengkapi dengan latihan

- التّيّيم berisi evaluasi yang terdiri atas 10 butir soal pilihan ganda meliputi 5 materi yang ada dalam المادّة dan sesuai dengan standar kompetensi dan kompetensi dasar yang telah ditetapkan.

- المفردات الصعبة yaitu berupa kamus katakata yang dianggap sulit yang sesuai dengan materi.

- الملف الثخصى yaitu profil berupa informasi mengenai biodata pengembang, dosen pembimbing, ahli materi dan ahli media.

\section{Evaluasi}

Setelah multimedia pembelajaran bahasa Arab selesai dikembangkan dan dikemas dalam bentuk $\mathrm{CD}$ atau berbentuk file pada flashdisk, maka proses penelitian dilanjutkan pada tahap validasi ahli dan revisi untuk menyempurnakan produk. Tahap validasi ini dilakukan oleh ahli materi bahasa Arab dan ahli media selanjutnya dilakukan uji coba lapangan hingga menghasilkan produk final.

Proses validasi materi pada multimedia pembelajaran bahasa Arab dengan cara memberikan softcopy produk multimedia dengan menggunakan flashdisk kepada validator dan dilengkapi dengan Satuan Acara Perkuliahan (SAP), printed out materi, dan instrument penilaian menggunakan angket skala likert yang mencakup aspek pembelajaran dan aspek materi.

Pelaksanaan validasi materi dengan cara validator membaca printed out materi yang telah disediakan dan membaca SAP untuk disesuaikan dengan materi kemudian validator ahli materi mencoba mengoperasikan multimedia pembelajaran dan mencermati materi serta memberikan penilaian, komentar, saran revisi yang berkaitan dengan aspek pembelajaran dan aspek materi.

Pelaksanaan validasi media oleh validator diawali dengan memberikan softcopy produk multimedia dengan menggunakan flashdisk kepada validator yang dilengkapi dengan flowchart, storyboard, dan instrumen penilaian berupa angket skala likert yang mencakup aspek tampilan dan pemrograman. Validator media mencermati produk multimedia serta memberi- 
kan penilaian, komentar dan saran berkaitan dengan aspek tampilan dan aspek pemrograman setelah mencermati produk.

\section{Data Hasil Validasi dan Revisi Ahli Materi}

\section{Ahli Materi I}

Validasi materi dalam penelitian ini dilakukan oleh dosen Pendidikan Bahasa Arab Pascasarjana UIN Sunan Kalijaga Bapak Tulus Musthafa. Lc. MA yang juga mengampu mata kuliah bahasa Arab di Prodi Pendidikan Bahasa Arab. Validasi oleh ahli materi dilakukan pada tanggal 02 Oktober 2012 pada pukul 16.20 di prodi PBA fakultas Tarbiyah lantai 4 ruang 401. Terdapat dua aspek yang dijadikan penilaian yaitu aspek materi dan aspek pembelajaran. Data validasi ahli materi diperoleh dengan cara memberikan produk dalam bentuk copyfile dari flashdisk dilengkapi dengan rencana pembelajaran, SAP, script materi, dan angket berskala 5 . Hasil penilaian ahli materi ini dapat dilihat pada Tabel 1.

Tabel 1. Rekap Rerata Skor Hasil Validasi Ahli Materi I

\begin{tabular}{llcccc}
\hline \multirow{2}{*}{ No } & \multirow{2}{*}{ Aspek Penilaian } & \multicolumn{4}{c}{ Skor } \\
\cline { 3 - 6 } & & Sebelum Revisi & Kategori & Sesudah Revisi & Kategori \\
\hline 1 & Materi & 3,6 & Baik & 4,4 & Sangat Baik \\
2 & Pembelajaran & 3,8 & Baik & 4,5 & Sangat Baik \\
& Jumlah & 7,4 & & 8,9 & \\
& Rata-rata & 3,7 & Baik & 4,45 & Sangat Baik \\
\hline
\end{tabular}

Setelah mengisi angket, ahli materi I memberikan saran untuk melakukan revisi produk. Adapun saran dari ahli materi adalah:

- Pada materi al-kalimah ash-sha'bah sebaiknya ditambahkan audio

- Pada evaluasi jika memungkinkan ditambahkan evaluasi maharatu al-istima' dan maharatu al-kalam agar evaluasi mencakup semua kompetensi bahasa sesuai dengan indikator yang dicapai.

Berdasarkan data pada tabel 3 Hasil penilaian ahli materi I terhadap kualitas produk ditinjau dari dua aspek yaitu aspek materi dan pembelajaran dapat diketahui bahwa rerata skor penilaian ahli materi adalah 4,45 dengan kategori "sangat baik" dan rerata dari aspek pembelajaran adalah 4,5 dengan kategori "sangat baik".

Berdasarkan rerata hasil validasi oleh ahli materi yang menunjukkan bahwa kelayakan materi pada multimedia pembelajaran bahasa Arab ini adalah "sangat baik", maka penelitian dilanjutkan ke tahap uji coba lapangan dengan terlebih dahulu melakukan revisi awal sesuai dengan saran dari ahli materi. Adapun tampilan hasil penilaian oleh ahli materi dapat dilihat pada gambar 1 berikut:

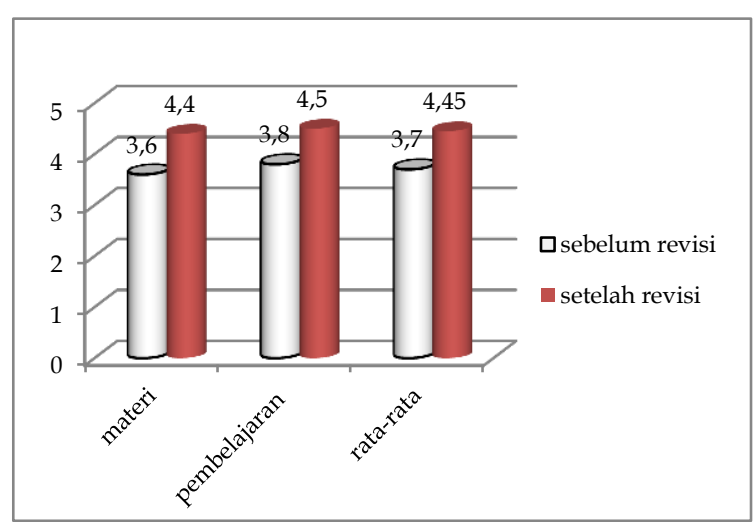

Gambar 1. Diagram Perolehan Rerata Skor Hasil Validasi Ahli Materi I

Ahli materi menilai bahwa materi multimedia pembelajaran bahasa Arab sudah sangat baik. Penambahan audio untuk mufrodat pada materi al-kalimah ash-sha'bah telah dilakukan agar kamus dapat lebih menarik dan membantu user untuk mengetahui cara baca mufrodat. Sehingga setiap user mengklik mufrodat maka secara otomatis audio berbunyi sesuai dengan teks mufrodat disertai dengan animasi didalam frame terjemah. 
Untuk evaluasi telah ditambahkan maharotul istima' tepatnya pada soal nomor 10 dengan meminta user mendengarkan sebuah mufrodat kemudian memilih jawaban pada opsi yang telah disediakan sesuai dengan mufrodat yang didengarkan. Perbaikan ini dapat dilihat pada gambar 2 berikut.

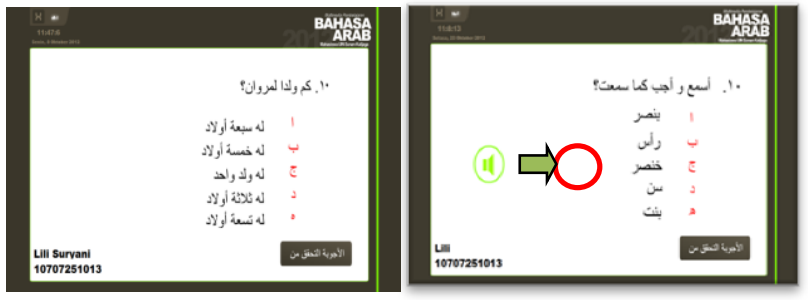

Sebelum direvisi Setelah direvisi

Gambar 2. Penggantian Soal No. 10

dari Maha-ratu al-Qira'ah Menjadi

Maharatu al-Istima'
Sedangkan untuk maharotu al-kalam tidak memungkinkan untuk ditambahkan karena kurangnya kemampuan dan pemahaman peneliti dalam pembuatan soal untuk maharotu al-kalam sehingga dapat dilakukan dengan praktik langsung oleh user atau pengajar dalam proses pembelajaran.

\section{$\underline{\text { Ahli Materi II }}$}

Validasi materi juga dilakukan oleh R. Umi Baroroh. M.Ag selaku dosen pengampu mata kuliah bahasa Arab pada tanggal 03 Oktober 2012 di ruang dosen Prodi Pendidikan Bahasa Arab Fakultas Tarbiyah dan Keguruan UIN Sunan Kalijaga Yogyakarta. Hasil penilaian ahli materi ini dapat dilihat pada Tabel 2.

Tabel 2. Rekap Rerata Skor Hasil Validasi Ahli Materi II

\begin{tabular}{clcccc}
\hline \multirow{2}{*}{ No } & \multirow{2}{*}{ Aspek Penilaian } & \multicolumn{4}{c}{ Skor } \\
\cline { 3 - 6 } & & Sebelum Revisi & Kategori & Sesudah Revisi & Kategori \\
\hline 1 & Materi & 3,2 & Baik & 4,3 & Sangat Baik \\
2 & Pembelajaran & 3,9 & Baik & 4,7 & Sangat Baik \\
& Jumlah & 7,1 & & 9 & \\
& Rata-rata & 3,55 & Baik & 4,5 & Sangat Baik \\
\hline
\end{tabular}

Ahli materi II memberikan saran revisi produk setelah memberikan penilaian pada multimedia pembelajaran bahasa Arab. Adapun saran revisi dari ahli materi II adalah:

- Menambahkan indikator pada muqaddimah agar tujuan pembelajaran lebih jelas

- Mengganti beberapa istilah pada frame

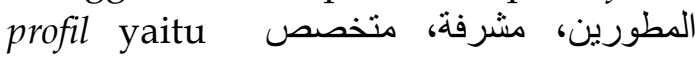
المحتوى، متخصص وسائل الاعلام.

Adapun hasil penilaian ahli materi II pada aspek materi mendapatkan rerata skor 4,3 kategori sangat baik. Adapun untuk aspek pembelajaran secara keseluruhan skor yang didapat dari aspek pembelajaran adalah 4,7 dengan kategori "sangat baik".

Berdasarkan rerata hasil validasi oleh ahli materi yang menunjukkan bahwa kelayakan materi pada multimedia pembelajaran bahasa Arab ini adalah "sangat baik", maka penelitian dilanjutkan ke tahap uji coba lapangan dengan terlebih dahulu melakukan revisi sesuai dengan saran dari ahli materi. Adapun tampilan hasil penilaian oleh ahli materi dapat dilihat pada Gambar 3 berikut.

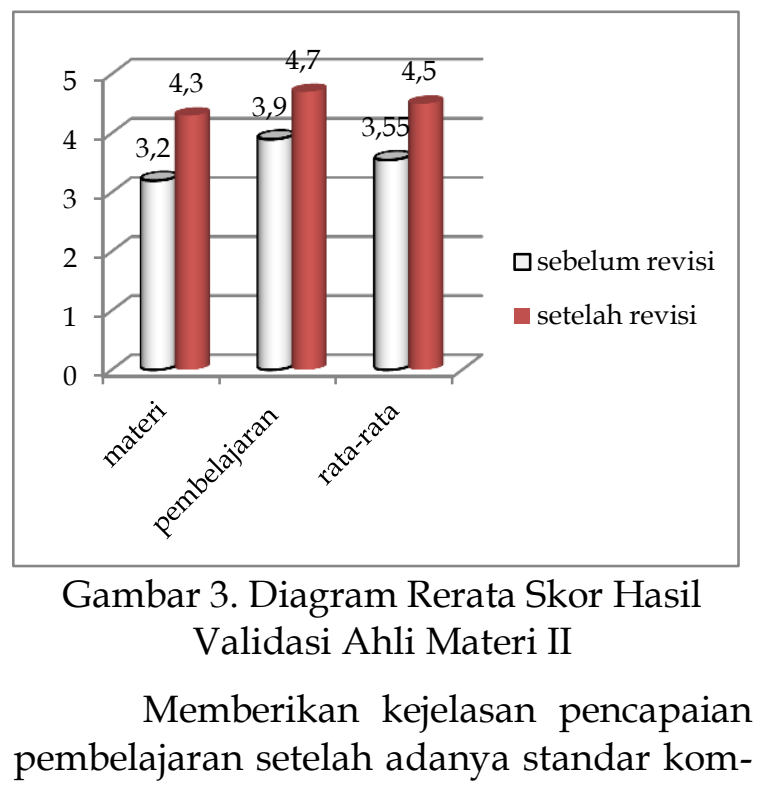


petensi dan kompetensi dasar yaitu indikator pencapaian pembelajaran. Tampilan sebelum dan sesudah revisi dapat dilihat pada gambar berikut:
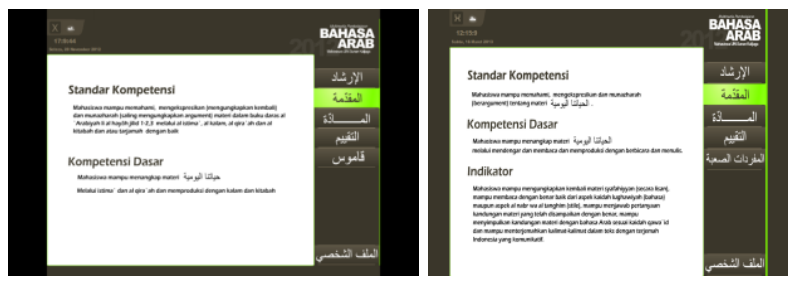

Sebelum direvisi setelah direvisi Gambar 4. Penambahan Indikator pada Halaman المقدمة

Mengganti beberapa istilah pada halaman profil dapat dilihat pada tabel 3 berikut:

Tabel 3. Beberapa Istilah yang Harus

Diganti pada Multimedia yang Dikembangkan

\begin{tabular}{|c|c|c|}
\hline No & Sebelum Revisi & Setelah Revisi \\
\hline 1 & المطورين & المطورة \\
\hline 2 & المشرفة & مشرفة \\
\hline 3 & متخصص محتوى & متحصص المحتوى \\
\hline 4 & المتخصص وسائل & سـائل الإعلام \\
\hline
\end{tabular}

Tampilan sebelum dan sesudah revisi dapat dilihat pada gambar berikut:

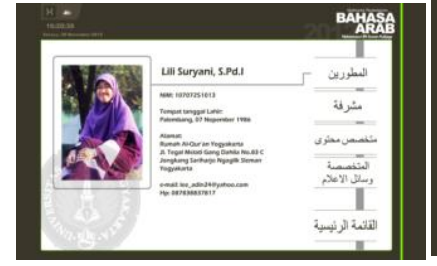

Sebelum direvisi

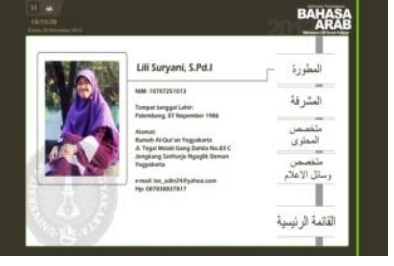

Setelah direvisi
Gambar 5. Tampilan Setelah Merubah Beberapa Istilah pada Halaman Profil

Data Hasil Uji Coba dan Revisi Ahli Media $\underline{\text { Ahli Media I }}$

Ahli media yaitu Dekan Fakultas Ilmu Pendidikan Dr. Haryanto yang dipilih berdasarkan kompetensi, keahlian dan pengalaman di bidang teknologi pembelajaran. Pemilihan juga berdasarkan persetujuan dosen pembimbing. Validasi oleh ahli media dilakukan pada tanggal 02 Oktober 2012. Terdapat dua aspek yang divalidasi oleh ahli media yaitu aspek tampilan (11 indikator) dan pemrograman (9 indikator) dengan keseluruhan pertanyaan 20 buah. Hasil penilaian ahli media ini dapat dilihat pada Tabel 4 berikut.

Tabel 4. Rekap Rerata Skor Hasil Validasi Ahli Media I

\begin{tabular}{clcccc}
\hline \multirow{2}{*}{ No } & \multirow{2}{*}{ Aspek Penilaian } & \multicolumn{4}{c}{ Skor } \\
\cline { 3 - 6 } & & Sebelum Revisi & Kategori & Sesudah Revisi & Kategori \\
\hline 1 & Tampilan & 3,27 & Baik & 4,36 & Sangat Baik \\
2 & Pemrograman & 3,55 & Baik & 4,33 & Sangat Baik \\
& Jumlah & 6,82 & & 8,69 & \\
& Rata-rata & 3,41 & Baik & 4,34 & Sangat Baik \\
\hline
\end{tabular}

Adapun saran dari ahli media I adalah mengenai:

- Mengganti logo UIN menjadi logo UNY

- Perlu pengelompokan tata letak mufrodat pada al-kalimah ash-sha'bah

- Opsi jawaban pada evaluasi harus seimbang

- Kunci jawaban untuk evaluasi harus proporsional.

Berdasarkan data pada tabel 4 hasil penilaian ahli media terhadap kualitas produk ditinjau dari dua aspek, yaitu aspek tampilan dan aspek pemrograman. Hasil perhitungan rerata skor pada aspek tam- pilan adalah 4,36 dengan kategori "sangat baik". Rerata dari aspek pemrograman ini adalah 4,33 dengan kategori "sangat baik". Secara keseluruhan rerata skor penilaian yang diperoleh dari ahli media adalah 4,34 dengan kategori "sangat baik". hasil ini menunjukkan bahwa multimedia layak untuk uji coba lapangan dengan terlebih dahulu melakukan revisi sesuai saran ahli media. Adapun tampilan hasil penilaian oleh ahli media dapat dilihat pada gambar berikut: 


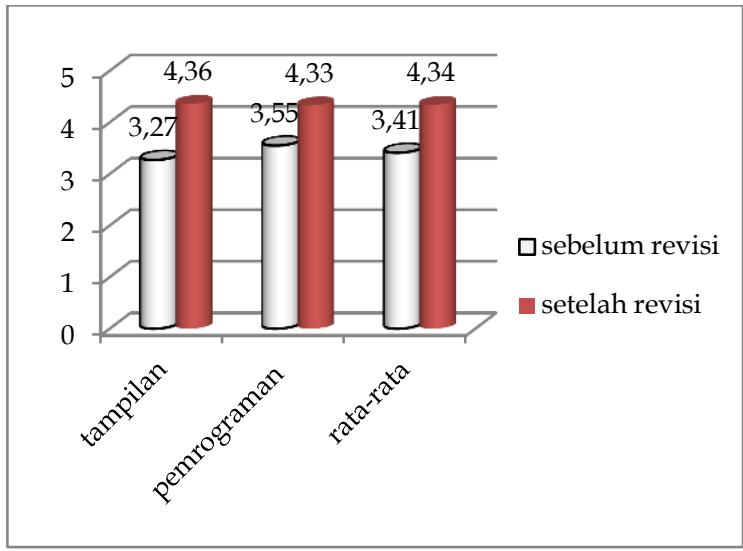

Gambar 5. Diagram Perolehan Rerata Skor Hasil Validasi oleh Ahli Media I

Berdasarkan saran yang diberikan oleh ahli media maka revisi yang dilakukan sebagai berikut:

- Penggunaan logo pada halaman judul disesuaikan dengan almamater pengembang. Tampilan sebelum dan sesudah revisi dapat dilihat pada Gambar 6.

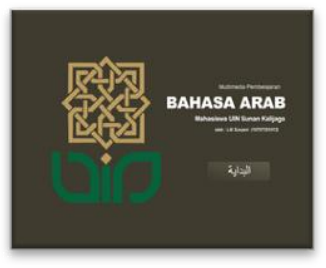

Sebelum direvisi

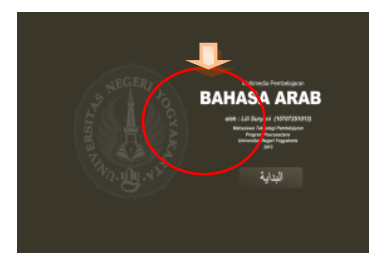

Setelah direvisi
Gambar 6. Tampilan Halaman Judul setelah Merubah Logo UIN menjadi Logo UNY

- Pengelompokan materi al-mufrodat ashsho'bah. Pengelompokan kamus dianggap penting untuk memudahkan mahasiswa mencari arti mufrodat yang tidak dipahami. Oleh sebab itu revisi dilakukan dengan mengelompokkan mufrodat berdasarkan judul materi. Tampilan perubahan materi berdasarkan judul materi dapat dilihat pada gambar berikut:

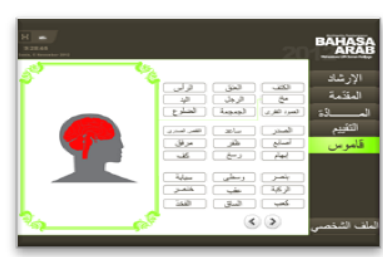

Sebelum direvisi
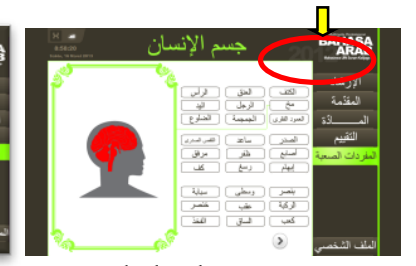

Setelah direvisi

Gambar 7. Tampilan Halaman al-Kalimah ash-Sha'bah Setelah Dikelompokkan
- Opsi jawaban dalam beberapa soal evaluasi tidak seimbang, sehingga daya beda soal menjadi lemah. Tampilan sebelum dan sesudah revisi dapat dilihat pada gambar berikut.

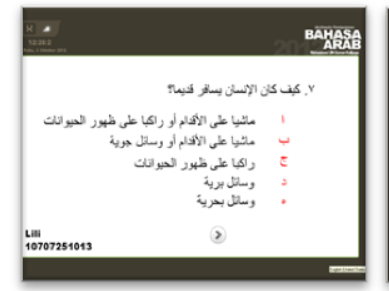

Sebelum direvisi

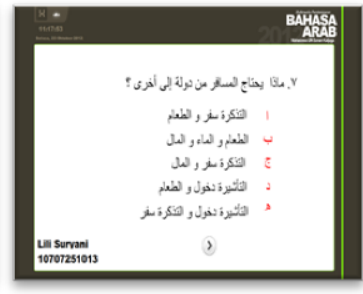

Setelah direvisi
Gambar 8. Tampilan Opsi Jawaban Evaluasi yang Lebih Seimbang

- Kunci jawaban pada evaluasi harus proporsional. Tampilan sebelum dan sesudah revisi dapat dilihat pada gambar berikut:

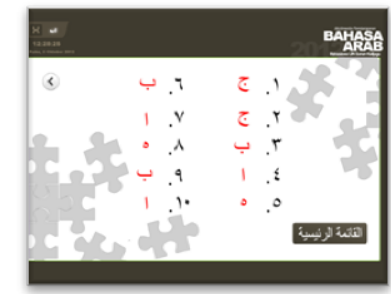

Sebelum direvisi

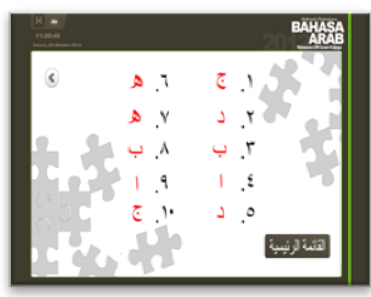

Setelah direvisi
Gambar 9. Tampilan Kunci Jawaban pada Evaluasi

\section{$\underline{\text { Ahli Media II }}$}

Validasi media juga dilakukan oleh Sigit Purnama, M.Pd selaku dosen pengampu mata kuliah pengembangan media pembelajaran bahasa Arab Prodi Pendidikan Bahasa Arab Fakultas Tarbiyah dan Keguruan UIN Sunan Kalijaga Yogyakarta pada tanggal 03 Oktober 2012 di ruang laboratorium komputer Fakultas Tarbiyah dan Keguruan UIN Sunan Kalijaga Yogyakarta. Hasil penilaian ahli media ini dapat dilihat pada Table 5 berikut. 
Tabel 5. Rekap Rerata Skor Hasil Validasi Ahli Media II

\begin{tabular}{cccccc}
\hline \multirow{2}{*}{ No } & \multirow{2}{*}{ Aspek Penilaian } & \multicolumn{3}{c}{ Skor } \\
\cline { 2 - 5 } & & Sebelum Revisi & Kategori & Sesudah Revisi & Kategori \\
\hline \multirow{2}{*}{2} & Tampilan & 3,81 & Baik & 5.5 & Sangat Baik \\
2 & Pemrograman & 3,22 & Baik & 4.4 & Sangat Baik \\
& Jumlah & 7,03 & & 9.9 & \\
& Rata-rata & 3,51 & Baik & 4.95 & Sangat Baik \\
\hline
\end{tabular}

Berdasarkan tabel 5, rerata pada aspek tampilan adalah 5.5 dengan kategori "sangat baik" sedangkan pada aspek pemrograman mendapatkan skor 4.4 dengan kategori "sangat baik". Secara keseluruhan rerata skor penilaian yang diperoleh dari ahli media adalah 4,34 dengan kategori "sangat baik". hasil ini menunjukkan bahwa multimedia layak untuk uji coba lapangan dan tanpa revisi karena tidak adanya saran dan komentar untuk perbaikan. Adapun tampilan hasil penilaian oleh ahli media dapat dilihat pada gambar berikut.

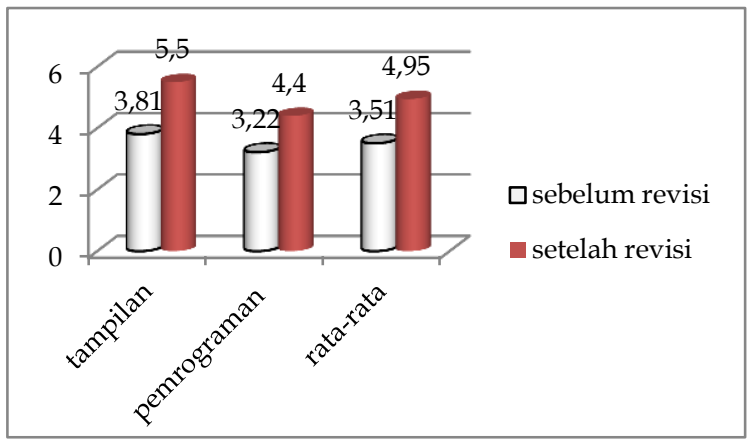

Gambar 10. Diagram Perolehan Rerata

Skor Hasil Validasi oleh Ahli Media II
Terkait dengan saran untuk perbaikan, ahli media II memberikan saran untuk mengganti font penulisan Arab pada multimedia diganti dengan yang lebih baik.

\section{Data Hasil Uji Coba Produk dan Revisi}

$\underline{\text { Uji Coba Satu-satu (one to one) }}$

Uji coba ini dilakukan pada tanggal 08 Oktober 2012 di ruang laboratorium komputer Fakultas Tarbiyah dan Pendidikan Prodi Pendidikan Bahasa Arab UIN Sunan Kalijaga Yogyakarta dengan responden sebanyak 3 orang mahasiswa. Uji coba dilakukan dengan menunjukkan produk dan menjelaskan secara singkat aplikasi penggunaan multimedia pembelajaran bahasa Arab kepada mahasiswa kemudian mahasiswa memberikan tanggapan mengenai kualitas produk dari segi kemudahan, kejelasan, dan daya tarik. Hasil penilaian mahasiswa dapat dilihat pada Tabel 6 berikut.

Tabel 6. Skor Penilaian Mahasiswa Uji Coba Satu-Satu

\begin{tabular}{|c|c|c|c|c|c|c|c|}
\hline \multirow{2}{*}{ No } & \multirow{2}{*}{ Aspek Penilaian } & \multicolumn{3}{|c|}{ Mhs } & \multirow{2}{*}{ Total skor } & \multirow{2}{*}{ Rerata } & \multirow{2}{*}{ Kategori } \\
\hline & & 1 & 2 & 3 & & & \\
\hline 1 & Kejelasan petunjuk penggunaan & 4 & 4 & 4 & 12 & 4,0 & Baik \\
\hline 2 & Kejelasan umpan balik & 4 & 5 & 3 & 12 & 4,0 & Baik \\
\hline 3 & Kejelasan teks & 5 & 3 & 4 & 12 & 4,0 & Baik \\
\hline 4 & Kejelasan gambar & 5 & 5 & 5 & 15 & 5,0 & Sangat baik \\
\hline 5 & Kejelasan animasi & 5 & 5 & 4 & 14 & 4,7 & Sangat baik \\
\hline 6 & Kemudahan memahami uraian materi & 4 & 5 & 3 & 12 & 4,0 & Baik \\
\hline 7 & Kemudahan dalam penggunaan berbagai navigasi & 5 & 4 & 5 & 14 & 4,7 & Sangat baik \\
\hline 8 & Ketertarikan terhadap materi & 4 & 5 & 5 & 14 & 4,7 & Sangat baik \\
\hline 9 & Kemudahan dalam mengerjakan soal & 4 & 5 & 4 & 13 & 4,3 & Sangat baik \\
\hline 10 & Kemudahan dalam membaca teks & 5 & 5 & 3 & 13 & 4,3 & Sangat baik \\
\hline 11 & Kemenarikan kombinasi warna & 3 & 5 & 4 & 12 & 4,0 & Baik \\
\hline 12 & Kemudahan dalam penggunaan kamus & 5 & 4 & 5 & 14 & 4,7 & Sangat baik \\
\hline 13 & Kejelasan audio & 4 & 4 & 4 & 12 & 4,0 & Baik \\
\hline \multirow[t]{3}{*}{14} & Kemenarikan program secara keseluruhan & 4 & 4 & 4 & 12 & 4,0 & Baik \\
\hline & Jumlah & & & & 181 & 60,4 & \multirow{2}{*}{ Sangat Baik } \\
\hline & Rerata & & & & & 4,3 & \\
\hline
\end{tabular}


Berdasarkan hasil uji coba satusatu, beberapa mahasiswa memberikan saran sebagai beruikut: "sebaiknya variasi warna pada multimedia tidak hanya abuabu dan hitam saja, sehingga perlu menambah variasi warna agar lebih menarik". Selain saran tersebut beberapa mahasiswa juga memberikan komentar berikut:

- Multimedia pembelajarannya sangat bagus dan penggunaannya mudah.

- Semoga multimedia ini dapat disempurnakan secepatnya sehingga dapat membantu dalam proses pembelajaran.

- Materi yang disajikan menjadi lebih menarik karena ada gambar dan suara, diiringi musik yang modern namun tetap Islami.

Berdasarkan Tabel 6 diketahui bahwa rerata hasil penilaian mahasiswa pada ujicoba satu-satu adalah 4,3 dengan kategori "sangat baik" adapun hasil penilaian mahasiswa terhadap multimedia pembelajaran bahasa Arab dapat dilihat pada gambar berikut:

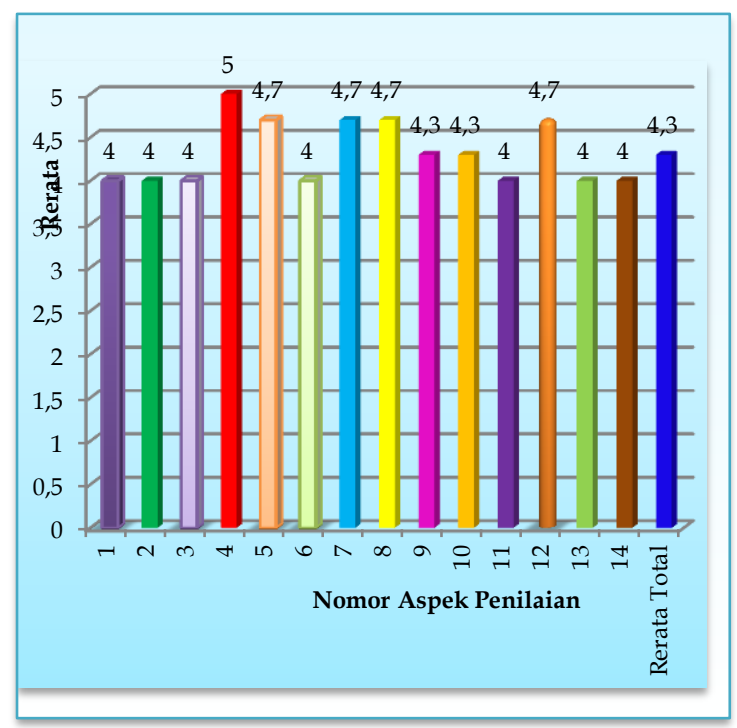

Gambar 11. Diagram Hasil Penilaian Mahasiswa pada Uji Coba Satu-satu

Jadi hasil penilaian mahasiswa terhadap multimedia pembelajaran bahasa Arab pada uji coba satu-satu adalah sangat baik. Hal ini dibuktikan dengan hasil rerata yang mencapai 4,3 (sangat baik) dan komentar yang positif dari mahasiswa yang dituliskan pada kolom komentar dan saran dalam lembar angket. Berdasarkan hasil tersebut, maka proses uji coba dapat dilanjutkan ke tahap berikutnya dengan terlebih dahulu melakukan revisi sesuai komentar dan saran dari mahasiswa.

Revisi produk dari mahasiswa ini dilakukan sesuai dengan saran dan komentar dari Ahmad Ardanu dan Ummu Hikmah Hafidzah yang menyatakan bahwa kurangnya variasi warna yang perlu ditambah hal ini dilakukan karena warna hanya kombinasi hitam dan abu-abu. Tampilan sebelum dan sesudah revisi dapat dilihat pada gambar 12 berikut:

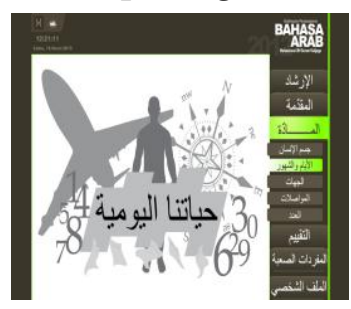

Sebelum direvisi

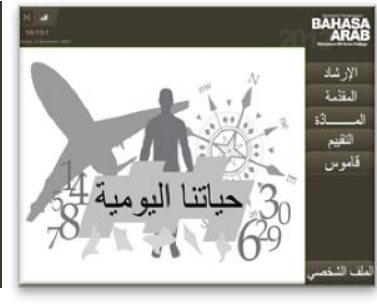

Setelah direvisi
Gambar 12. Tampilan Halaman Judul Setelah Menambah Warna Tombol

\section{Uji Coba Kelompok Kecil (small group evaluation)}

Uji coba ini dilaksanakan pada hari sabtu tanggal 13 Oktober 2012 kepada mahasiswa PBA Fakultas Tarbiyah dan Keguruan UIN Sunan Kalijaga Yogyakarta dengan responden yang berjumlah 10 orang mahasiswa. Uji coba dilakukan di Laboratorium Komputer Fakultas Tarbiyah dan Keguruan dengan menunjukkan produk kepada mahasiswa dan mahasiswa mengoperasikan produk di komputer, selanjutnya mahasiswa memberikan tanggapan mengenai kualitas produk dari segi kemudahan, kejelasan dan daya tarik. Hasil penilaian mahasiswa dapat dilihat pada Tabel 7 berikut. 
Tabel 7. Rekap Rerata Hasil Uji Coba Kelompok Kecil

\begin{tabular}{|c|c|c|c|c|c|c|c|c|c|}
\hline \multirow{2}{*}{ No } & \multirow{2}{*}{ Aspek Penilaian } & \multicolumn{5}{|c|}{ Skor Penilaian } & \multirow[t]{2}{*}{ Total skor } & \multirow{2}{*}{ Rerata } & \multirow{2}{*}{ Kategori } \\
\hline & & 1 & 2 & 3 & 4 & 5 & & & \\
\hline 1 & Kejelasan petunjuk penggunaan & & & 6 & 20 & 15 & 41 & 4,1 & Baik \\
\hline 2 & Kejelasan umpan balik & & & 9 & 14 & 25 & 48 & 4,8 & Sangat baik \\
\hline 3 & Kejelasan teks & & 2 & 3 & 4 & 35 & 44 & 4,4 & Sangat baik \\
\hline 4 & Kejelasan gambar & & & 6 & 24 & 10 & 40 & 4,0 & Baik \\
\hline 5 & Kejelasan animasi & & & 3 & 12 & 20 & 35 & 3,5 & Baik \\
\hline 6 & Kemudahan memahami uraian materi & & 2 & 9 & 12 & 15 & 38 & 3,8 & Baik \\
\hline 7 & Kemudahan dalam penggunaan berbagai navigasi & & & 3 & 16 & 25 & 44 & 4,4 & Sangat baik \\
\hline 8 & Ketertarikan terhadap materi & & & & 20 & 25 & 45 & 4,5 & Sangat baik \\
\hline 9 & Kemudahan dalam mengerjakan soal & & & 12 & 16 & 10 & 38 & 3,8 & Baik \\
\hline 10 & Kemudahan dalam membaca teks & & 2 & 6 & 24 & 5 & 37 & 3,7 & Baik \\
\hline 11 & Kemenarikan kombinasi warna & & 2 & 6 & 12 & 20 & 40 & 4,0 & Baik \\
\hline 12 & Kemudahan dalam penggunaan kamus & & 2 & 3 & 12 & 25 & 42 & 4,2 & Baik \\
\hline 13 & Kejelasan audio & & 4 & 6 & 8 & 20 & 38 & 3,8 & Baik \\
\hline 14 & Kemenarikan program secara keseluruhan & & 2 & & 16 & 25 & 43 & 4,3 & Sangat baik \\
\hline \multicolumn{2}{|c|}{ Jumlah } & & & & & & 573 & 57,3 & \multirow{2}{*}{ Baik } \\
\hline \multicolumn{2}{|c|}{ Rerata } & & & & & & & 4,1 & \\
\hline
\end{tabular}

Berdasarkan hasil uji coba kelompok kecil, tidak terdapat saran untuk melakukan revisi dari mahasiswa. Adapun beberapa komentar singkat yang dinyatakan mahasiswa mengenai multimedia pembelajaran bahasa Arab pada uji kelompok kecil ini, yaitu:"Like This”, "Mudah dimengerti", "It's so good" dan "Bravo bu, semoga secepatnya bisa kami gunakan dalam belajar mandiri"

Berdasarkan data pada tabel 7, rerata hasil penilaian mahasiswa pada uji coba kelompok kecil dengan responden 10 mahasiswa adalah 4,1 (baik). Tampilan penilaian seluruh mahasiswa terhadap multimedia pembelajaran bahasa Arab dapat dilihat pada gambar 9 .

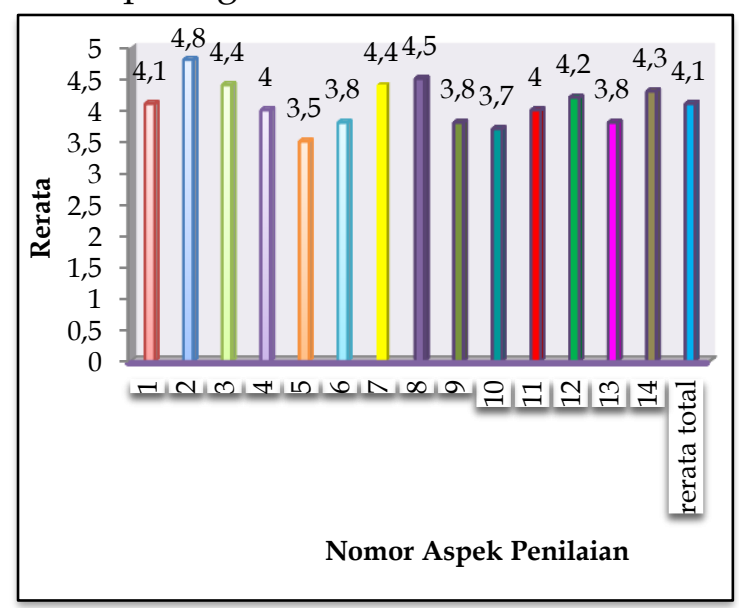

Gambar 13. Diagram Hasil Penilaian Mahasiswa Pada Uji Coba Kelompok Kecil
Berdasarkan analisis data, maka hasil penilaian mahasiswa terhadap multimedia pembelajaran bahasa Arab pada uji coba kelompok kecil adalah "baik". Hal ini dibuktikan dengan hasil rerata yang dicapai adalah 4,1. Berdasarkan hasil tersebut, maka proses uji coba produk multimedia pembelajaran bahasa Arab dapat dilanjutkan pada tahap akhir yaitu uji lapangan.

\section{Uji Coba Lapangan (field trial)}

Uji lapangan ini dilakukan pada hari sabtu tanggal 20 Oktober 2012 di ruang laboratorium komputer Fakultas Tarbiyah dan Keguruan dengan responden 20 orang mahasiswa Prodi Pendidikan Bahasa Arab UIN Sunan Kalijaga Yogyakarta.

Uji coba dilakukan secara bertahap sebanyak dua sesi. Hal ini dilakukan karena jumlah komputer yang ada di laboratorium komputer yang dapat digunakan untuk uji coba berjumlah 14 unit. Sehingga prosedur uji coba lapangan dilakukan dengan membagi mahasiswa menjadi 2 kelompok, yaitu kelompok pertama 10 orang mahasiswa dan kelompok kedua juga terdiri atas 10 orang mahasiswa.

Uji coba dilakukan dengan menunjukkan produk kepada mahasiswa dengan menjelaskan beberapa hal yang berkaitan 
dengan penggunaan multimedia pembelajaran bahasa Arab, kemudian mahasiswa mengoperasikan produk di komputer secara mandiri dengan sesekali bertanya jika menemukan sesuatu yang tidak dipahami, selanjutnya mahasiswa memberi- kan tanggapan mengenai kualitas produk dari segi kemudahan, kejelasan dan daya tarik dengan mengisi angket dan memberikan komentar dan saran yang telah disediakan. Hasil penilaian mahasiswa dapat dilihat pada Tabel 8 berikut.

Tabel 8. Rekap Rerata Hasil Uji Lapangan

\begin{tabular}{|c|c|c|c|c|c|c|c|c|c|}
\hline \multirow{2}{*}{ No } & \multirow{2}{*}{ Aspek Penilaian } & \multicolumn{5}{|c|}{ Skor Penilaian } & \multirow[t]{2}{*}{ Total skor } & \multirow{2}{*}{ Rerata } & \multirow{2}{*}{ Kategori } \\
\hline & & 1 & 2 & 3 & 4 & 5 & & & \\
\hline 1 & Kejelasan petunjuk penggunaan & & & 3 & 44 & 40 & 87 & 4,4 & Sangat baik \\
\hline 2 & Kejelasan umpan balik & & & 6 & 44 & 35 & 85 & 4,3 & Sangat baik \\
\hline 3 & Kejelasan teks & & & 3 & 48 & 35 & 86 & 4,3 & Sangat baik \\
\hline 4 & Kejelasan gambar & & & 3 & 48 & 35 & 86 & 4,3 & Sangat baik \\
\hline 5 & Kejelasan animasi & & & 9 & 32 & 45 & 86 & 4,3 & Sangat baik \\
\hline 6 & Kemudahan memahami uraian materi & & & 6 & 52 & 25 & 83 & 4,2 & Baik \\
\hline 7 & Kemudahan dalam penggunaan berbagai navigasi & & & & 36 & 55 & 91 & 4,6 & Sangat baik \\
\hline 8 & Ketertarikan terhadap materi & & & 3 & 44 & 40 & 87 & 4,4 & Sangat baik \\
\hline 9 & Kemudahan dalam mengerjakan soal & & & 15 & 36 & 30 & 81 & 4,1 & Baik \\
\hline 10 & Kemudahan dalam membaca teks & & & 12 & 40 & 30 & 82 & 4,1 & Baik \\
\hline 11 & Kemenarikan kombinasi warna & & 2 & 18 & 36 & 20 & 76 & 3,8 & Baik \\
\hline 12 & Kemudahan dalam penggunaan kamus & & & 15 & 20 & 50 & 85 & 4,3 & Baik \\
\hline 13 & Kejelasan audio & & & 18 & 40 & 20 & 78 & 3,9 & Baik \\
\hline 14 & Kemenarikan program secara keseluruhan & & & 3 & 52 & 30 & 85 & 4,3 & Sangat baik \\
\hline \multicolumn{2}{|c|}{ Jumlah } & & & & & & 1178 & 59,3 & \multirow{2}{*}{ Sangat baik } \\
\hline \multicolumn{2}{|c|}{ Rerata } & & & & & & & 4,23 & \\
\hline
\end{tabular}

Berdasarkan hasil analisis instrumen penilaian yang diberikan kepada mahasiswa tidak ada saran yang disampaikan. Namun ada beberapa komentar yang disampaikan mahasiswa mengenai multimedia pembelajaran bahasa Arab ini, yaitu: (1) "Secara keseluruhan multimedia pembelajaran bahasa Arab ini baik dan sangat membantu"; (2) "Lebih menguasai materi dengan belajar menggunakan ini, tidak membosankan, tidak buat ngantuk, unik, menarik; (3) "Multimedia pembelajaran bahasa Arabnya sudah sangat baik. Tingkatkan untuk menjadi lebih baik agar mahasiswa lebih tertarik dalam belajar".

Berdasarkan data pada tabel 8, rerata hasil penilaian seluruh mahasiswa pada uji lapangan adalah 4,23 (sangat baik). Tampilan keseluruhan penilaian mahasiswa terhadap multimedia pembelajaran bahasa Arab yang dikembangkan dalam penelitian ini dapat dilihat pada Gambar 14.

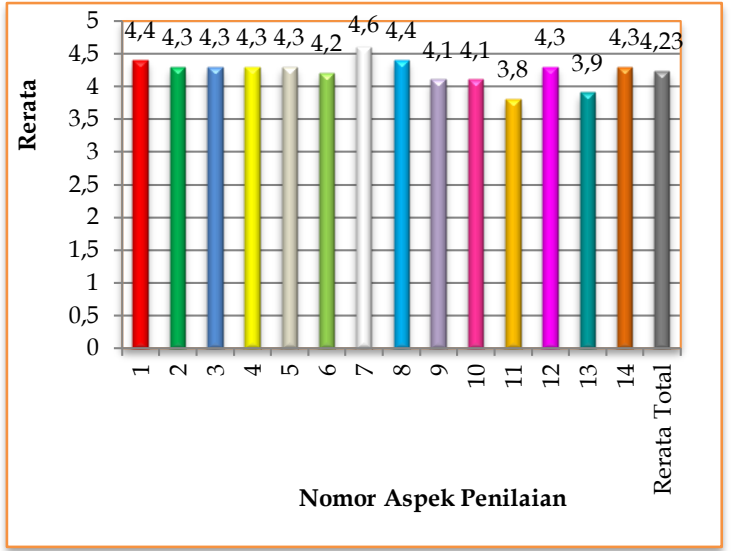

Gambar 14. Diagram Hasil Penilaian Seluruh Mahasiswa pada Uji Lapangan

Berdasarkan analisis data, hasil penilaian mahasiswa terhadap multimedia pembelajaran bahasa Arab pada uji lapangan adalah sangat baik. Hal ini dibuktikan dengan hasil rerata yang dicapai adalah 4,23 (sangat baik). Berdasarkan hasil tersebut, maka multimedia pembelajaran bahasa Arab untuk mahasiswa Prodi Pendidikan Bahasa Arab dapat dinyatakan 
"layak" untuk digunakan dalam pembelajaran mata kuliah Bahasa Arab.

\section{Deskripsi Data Hasil Uji Coba Keefektifan Multimedia Hasil Pengembangan}

Uji coba keefektifan ini dilakukan untuk mengetahui kelayakan dan keefektifan produk hasil pengembangan dalam proses pembelajaran bahasa Arab dengan melihat peningkatan ketuntasan belajar mahasiswa sebelum dan setelah menggunakan multimedia pembelajaran bahasa Arab yang dikembangkan. Proses pelaksanaan penggunaan multimedia dalam pembelajaran bahasa Arab ini dilaksanakan pada hari selasa dan rabu 27 dan 28 Nopember 2012 di laboratorium bahasa Fakultas Tarbiyah dan Keguruan UIN Sunan Kalijaga Yogyakarta yang diikuti oleh 29 mahasiswa dan didampingi oleh dosen pengampu mata kuliah bahasa Arab 1 dan 2.

Pelaksanaan pembelajaran menggunakan multimedia bahasa Arab hasil pengembangan diawali dengan memberikan pemahaman awal tentang multimedia pembelajaran bahasa Arab kepada mahasiswa kemudian menjelaskan materi dalam multimedia secara singkat dan menjelaskan kompetensi dasar dan indikator yang akan dicapai dalam pembelajaran bahasa Arab menggunakan multimedia hasil pengembangan. Membagikan CD pembelajaran hasil pengembangan kepada mahasiswa dan memberikan kesempatan kepada mahasiswa untuk mengeksplore berbagai komponen yang terdapat dalam $C D$ pembelajaran dengan terus memberikan bimbingan untuk memudahkan mahasiswa menggunakan multimedia hasil pengembangan serta memberikan kesempatan kepada mahasiswa untuk belajar secara mandiri.

Berdasarkan hasil uji coba keefektifan multimedia hasil pengembangan kepada mahasiswa dapat diketahui perbandingan nilai yang diperoleh mahasiswa yaitu nilai terendah, nilai tertinggi, rerata dan selisih nilai pre-test dan post-test ( $N$ -
Gain skor). Data yang diperoleh dapat divisualisasikan pada Tabel 9.

Tabel 9. Hasil Uji Efektivitas

Multimedia Hasil Pengembangan

Pembelajaran Bahasa Arab

\begin{tabular}{llccc}
\hline No & \multicolumn{1}{c}{ Nilai } & $\begin{array}{r}\text { Pre- } \\
\text { test }\end{array}$ & $\begin{array}{c}\text { Post- } \\
\text { test }\end{array}$ & $\begin{array}{c}\text { Gain } \\
\text { score }\end{array}$ \\
\hline 1 & Nilai Terendah & 30 & 70 & \\
2 & Nilai Tertinggi & 90 & 100 & 23.4 \\
3 & Total & 1870 & 2550 & \\
4 & Rata-rata & 64.5 & 87.9 & \\
\hline
\end{tabular}

Hasil pre-test dan post-test juga menentukan ketuntasan hasil belajar yang dicapai oleh mahasiswa dalam menggunakan multimedia pembelajaran bahasa Arab. Perbedaan ketuntasan hasil belajar sebelum dan setelah menggunakan multimedia pembelajaran bahasa Arab dapat divisualisasikan pada Tabel 10 berikut.

Tabel 10. Ketuntasan Hasil Belajar Bahasa Arab Mahasiswa PBA UIN Sunan Kalijaga

\begin{tabular}{llcccc}
\hline \multirow{2}{*}{ No } & \multirow{2}{*}{ Ketuntasan } & \multicolumn{2}{c}{ Pre-test } & \multicolumn{2}{c}{ Post-test } \\
\cline { 3 - 6 } & & Jumlah & $\%$ & Jumlah & $\%$ \\
\hline \multirow{2}{*}{1} & Tuntas & 14 & 48,3 & 29 & 100 \\
2 & Tidak tuntas & 15 & 51,7 & 0 & 0 \\
& Jumlah & 29 & 100 & 29 & 100 \\
\hline
\end{tabular}

Berdasarkan tabel 10 dapat diketahui bahwa terdapat perbedaan nilai antara sebelum dan sesudah melaksanakan pembelajaran dengan menggunakan multimedia pembelajaran bahasa Arab. Perbedaan tersebut ditunjukkan pada: (a) ratarata belajar bahasa Arab mahasiswa meningkat dari 64.5 menjadi 87.9 dengan selisih antara rerata pre-test dan post-test atau disebut gain score sebesar 23.4 poin; (b) peningkatan hasil belajar dapat membantu mahasiswa memperoleh ketuntasan belajar sebanyak 100\% sesuai standar KKM dari prodi PBA UIN Sunan Kalijaga Yogyakarta, yaitu $\geq 70$; (c) hasil pre-test menunjukkan bahwa 14 Mahasiswa dapat menuntaskan pembelajaran sehingga persentase ketuntasan hanya $48.3 \%$; (d) hasil posttest menunjukkan bahwa seluruh mahasiswa dapat menuntaskan pembelajaran sehingga persentase meningkat menjadi 
$100 \%$; (e) nilai tertinggi pada saat pre-test adalah 90 sedangkan nilai terendah adalah 30; (f) nilai tertinggi pada saat post-test adalah 100 dan nilai terendah adalah 70 .

Adapun tampilan mengenai peningkatan hasil belajar ini dapat divisualisasikan pada gambar berikut.

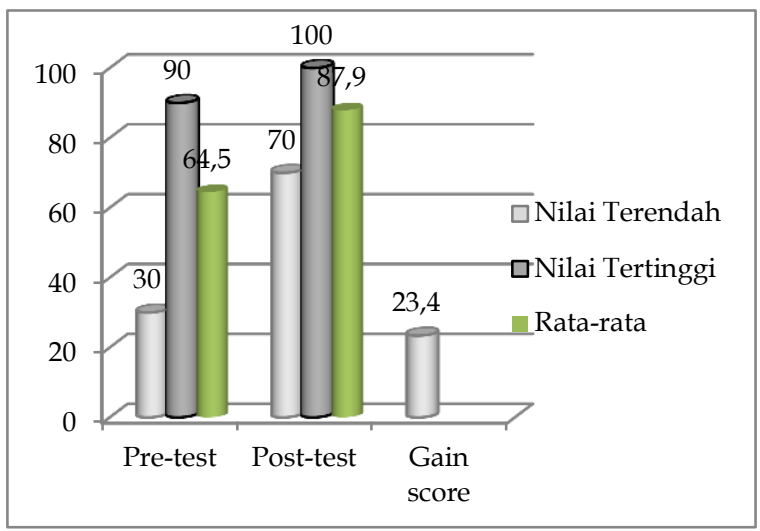

Gambar 15. Diagram Hasil Analisis Nilai Mahasiswa pada Pre-Test dan Post-Test

Adapun tampilan ketuntasan belajar ini dapat divisualisasikan sebagai berikut:

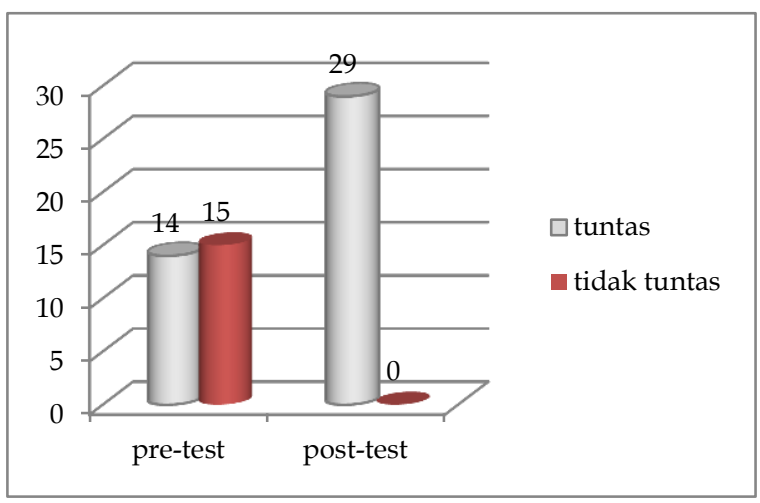

Gambar 12. Diagram Ketuntasan Hasil Belajar Mahasiswa pada Pre-Test dan Post-Test

Berdasarkan uraian data yang diperoleh dari hasil pre-test dan post-test mengenai ketuntasan belajar. Maka dapat disimpulkan bahwa penggunaan multimedia pembelajaran bahasa Arab dalam proses pembelajaran bahasa Arab pada mahasiswa Prodi Pendidikan Bahasa Arab UIN Sunan Kalijaga Yogyakarta dapat meningkatkan hasil belajar mahasiswa dan tuntas dalam belajar. Pencapaian ini membuktikan bahwa multimedia pembelajaran bahasa Arab efektif untuk digunakan dalam pembelajaran.

\section{Simpulan dan Saran}

\section{Simpulan}

Dari uraian hasil penelitian tersebut dapat disimpulkan sebagai berikut. Pertama, Produk multimedia yang dihasilkan adalah multimedia pembelajaran bahasa Arab dengan materi pokok "kehidupan sehari-hari" (حياتتا اليومية) dengan 5 sub pokok bahasan untuk mahasiswa Prodi Pendidikan Bahasa Arab Fakultas Tarbiyah dan Keguruan UIN Sunan Kalijaga Yogyakarta pada semester I. Multimedia hasil pengembangan ini telah layak dan terbukti efektif digunakan dalam pembelajaran dibuktikan berdasarkan hasil validasi ahli materi dan validasi ahli media serta hasil uji coba kepada mahasiswa. Multimedia ini dapat digunakan dalam pembelajaran baik secara klasikal maupun individual dan untuk petunjuk penggunaan dapat dibaca pada manual book.

Kedua, Multimedia hasil pengembangan ini layak dan efektif digunakan sebagai sumber belajar berdasarkan hasil belajar mahasiswa pada uji keefektifan penggunakan multimedia pembelajaran bahasa Arab dengan memperoleh rerata sebesar 64,5 pada saat pre-test sedangkan hasil belajar mahasiswa pada saat post-test memperoleh rerata 87,9 . Berdasarkan hasil tersebut diperoleh gain score 23,4 poin, sehingga pembelajaran menggunakan multimedia hasil pengembangan ini tuntas $100 \%$.

\section{Saran}

Penelitian pengembangan pembelajaran Bahasa Arab selanjutnya, hendaknya memperhatikan kebutuhan pembelajar sehingga produk yang dikembangkan dapat membantu dan memberikan kontribusi besar dalam meningkatkan minat belajar, menghilangkan pemikiran bahwa belajar bahasa Arab sulit dan tidak ada media yang interaktif. Hal ini penting karena masih belum tercukupinya multimedia pembelajaran bahasa Arab terutama untuk pemula dan calon pendidik bahasa Arab.

Untuk pengembangan multimedia bahasa Arab ini lebih lanjut dapat diteliti dan dikembangkan lebih baik lagi ter- 
utama kelengkapan komponen multimedia yang belum ada seperti menambahkan fasilitas untuk meningkatkan kemampuan berbicara, menambahkan video, gambar, animasi dan dilengkapi dengan game yang menarik dan sesuai dengan materi serta mengembangkan lebih banyak multimedia untuk materi-materi yang lain.

\section{Daftar Pustaka}

AECT. (1997). The definition of educational technology: AECT task force on definition and terminology. Washington, DC: Associations for Educational Communications and Technology (AECT).

Borg, Walter \& Gall, Meredith Damien. (1989). Educational research. New York \& London: Longman.

Chapman, N., \& Chapman, J. (2004). Digital multimedia $\left(2^{\text {nd }}\right.$ ed). England: Jhon Wiley \& Sons, Ltd.
Dick, W., \& Carey, L. (2005). The systematic design of instruction. New York: Addison-Wesley Education Publisher, Inc

Kim \& Gillman (2008). Effect of text, audio, and graphic aids in multimedia instruction for vocabulary learning" Journal Educational Technology $\mathcal{E}$ Society

Lee, W.W., \& Owens, D.L (2004) Multimedia base instruction design: Computer based training, web based training, distance broadcast training, performance based solution ( $2^{\text {nd }}$ ed). San Fransisco: Pfeiffer A Wiley Imprint.

Philips, R. (1997). A practical guide for education applications. London: Kogan Page limited.

Sukarjo. (2006). Evaluasi pembelajaran. Diktat mata kuliah, tidak diterbitkan. Pascasarjana Universitas Yogyakarta, Yogyakarta. 